\title{
Badania środków poprawiających stabilność sedymentacyjną zaczynów cementowych
}

\section{Tests on agents improving the sedimentation stability of cement slurries}

\author{
Marcin Kremieniewski \\ Instytut Nafty i Gazu - Państwowy Instytut Badawczy
}

\begin{abstract}
STRESZCZENIE: Podczas projektowania zaczynów o obniżonej gęstości, jedną z większych trudności jest uzyskanie homogenicznej struktury zaczynu zarówno w stanie płynnym, jak i po związaniu. Problem ten wynika głównie z obecności lekkich dodatków wypełniających w objętości zaczynu. Materiały te na skutek frakcjonowania unoszą się w górnych partiach cementowanej przestrzeni pierścieniowej. Z kolei ziarna cementu, które charakteryzują się większą gęstością, w wyniku sedymentacji osiadają w dolnej części otworu. Takie zachowanie zaczynu jest niekorzystne. Powstały z tak niejednorodnego zaczynu płaszcz cementowy będzie wykazywał bardzo niskie wartości wytrzymałości na ściskanie w górnych partiach uszczelnianej kolumny rur, co wpływa na słabą ich stabilizację. Dodatkowo płaszcz cementowy posiadał będzie dużą przepuszczalność, co skutkuje brakiem skuteczności uszczelnienia poszczególnych sekcji rur. W celu wyeliminowania tego niepożądanego zjawiska nadmiernego frakcjonowania i sedymentacji zaczynu lekkiego stosuje się różnego rodzaju środki poprawiające stabilność sedymentacyjną. Środki tego typu są poddawane badaniom w zaczynie cementowym. Jednak znacznie dokładniejszym pomiarem możliwości przeciwdziałania frakcjonowania danego środka przeciwsedymentacyjnego jest badanie go w wodzie. Związane jest to $\mathrm{z}$ faktem, iż zaczyn cementowy ze względu na obecność w nim dodatkowych środków i domieszek wykazuje wyższą lepkość plastyczną. W związku z tym w niniejszej publikacji przedstawiono wyniki badań środków poprawiających stabilność sedymentacyjną poprzez określanie wpływu ich działania na mikrosferę w cieczy niskolepkiej, jaką jest woda. W artykule przedstawiono metodykę pomiaru frakcjonowania wypełniacza lekkiego i działania przeciwsedymentacyjnego wybranych środków poprawiających stabilność sedymentacyjną zaczynów cementowych. Podczas realizacji prac badawczych skoncentrowano się głównie na określeniu frakcjonowania mikrosfer w wodzie zarobowej o określonym stężeniu środków poprawiających stabilność sedymentacyjną. Do badań wytypowano 6 rodzajów środków, które użyto w koncentracji od 0,5\% do 10\%. Wykonane zostały badania frakcjonowania mikrosfer w jednostce czasu, na podstawie czego możliwe było określenie skuteczności działania danego środka ograniczającego frakcjonowanie w celu sporządzenia zaczynu lekkiego o odpowiedniej stabilności sedymentacyjnej.
\end{abstract}

Słowa kluczowe: zaczyn cementowy lekki, stabilność sedymentacyjna, frakcjonowanie, środki przeciwsedymentacyjne.

ABSTRACT: When designing slurries with reduced density, one of the biggest difficulties is obtaining a homogeneous slurry structure both in liquid state and after setting. This problem is mainly due to the presence of light fillers in the slurry volume. Due to fractionation, these materials float in the upper parts of the cemented annular space. In turn, cement grains, which are characterized by higher density, as a result of sedimentation settle in the bottom of the hole. This cement slurry behavior is unfavorable. The cement sheath resulting from such heterogeneous cement slurry will show very low values of compressive strength in the upper parts of the sealed column of pipes, yielding poor stabilization. In addition, the cement sheath will have high permeability, which results in the lack of sealing efficiency of individual pipe sections. In order to eliminate this undesirable phenomenon of excessive fractionation and sedimentation of lightweight cement slurry, various agents are used to improve sedimentation stability. Agents of this type are tested in cement slurry. However, a much more accurate measurement of the possibility of counteracting the fractionation of a given anti-sedimentation agent is testing it in water. This is due to the fact that the presence of additional additives and admixtures in the cement slurry results in its higher plastic viscosity. Therefore, this publication presents the results of research on agents that improve sedimentation stability by determining their impact on the microsphere in a low-viscous liquid, which is water. The article presents the methodology for measuring light filler fractionation and anti-sedimentation effect of selected agents improving the sedimentation stability of cement slurries. During the implementation of research, the focus was mainly on determining the fractionation of microspheres in mixing water with a specific concentration of agents that improve sedimentation stability. Six types of agents were selected for research, which were used in concentrations from $0.5 \%$ to $10 \%$. Microsphere fractionation tests were performed per unit of time, based on which it was possible to determine the effectiveness of a given fractionation limiting agent in order to prepare a lightweight cement slurry with appropriate sedimentation stability.

Key words: lightweight cement slurry, sedimentation stability, fractionation, anti-sedimentation agents.

Autor do korespondencji: M. Kremieniewski, e-mail: marcin.kremieniewski@inig.pl

Artykuł nadesłano do Redakcji: 06.02.2020 r. Zatwierdzono do druku: 27.05.2020 r. 


\section{Wprowadzenie}

Odpowiednia izolacja stref przepuszczalnych w przestrzeni pozarurowej zależy przede wszystkim od odpowiednio zaprojektowanego składu zaczynu. Występujące niekiedy specyficzne warunki geologiczne, na przykład rejon występowania skał słabozwięzłych, wymusza stosowanie zaczynów o niskiej gęstości (Kremieniewski, 2019b; Kremieniewski i Stryczek, 2019). Receptura tego rodzaju określana mianem zaczynu lekkiego pozwala na utrzymanie niskich wartości ciśnienia hydrostatycznego w cementowanej przestrzeni pierścieniowej bądź pozarurowej, przez co wyeliminowane zostaje prawdopodobieństwo wnikania zaczynu w strefy słabozwięzłe. Podczas projektowania takich receptur stosuje się wypełniacze lekkie, które pozwalają odpowiednio obniżyć gęstość zaczynu (Kremieniewski et al., 2016; Kremieniewski, 2017b). Jednak ze względu na zróżnicowanie gęstości ziaren wypełniaczy lekkich, niejednokrotnie zachodzi zjawisko frakcjonowania, w wyniku którego lekkie drobiny unoszą się w górne partie próbki. Występuje również sedymentacja, podczas której ciężkie frakcje opadają $\mathrm{w}$ dolne partie cementowanej przestrzeni pierścieniowej (rys. 1) (Kremieniewski 2017a; Jordan et al., 2018). Zjawisko takie jest niedopuszczalne w technologii zaczynów cementowych, ponieważ powstały z takiej receptury płaszcz cementowy będzie wykazywał brak jednorodności struktury. Płaszcz cementowy w górnych partiach charakteryzował się będzie niskimi wartościami wytrzymałości na ściskanie wynikającymi ze znacznie podwyższonej wartości współczynnika porowatości oraz nie będzie stanowił izolacji ze względu na dużą przepuszczalność (Kremieniewski, 2018). Dolna część otworu może ulec rozszczelinowaniu na skutek zbyt dużej gęstości zaczynu, w którym ciężkie frakcje przemieszczą się w ten rejon cementowanej przestrzeni. Natomiast w środkowej części na skutek wydzielania się znacznych ilości wody mogą powstawać „kieszenie wodne” i drogi migracji gazu (rys. 2).

Nadmierne frakcjonowanie składników zaczynu cementowego bądź wydzielenie znacznej ilości wody wolnej można w znacznym stopniu ograniczyć poprzez zastosowanie odpowiednich dodatków i domieszek. Materiały takie przeciwdziałają wytrącaniu cząsteczek powodując utrzymanie stabilnej wartości granicy płynięcia na poziomie umożliwiającym utrzymanie cyrkulacji oraz oporów hydraulicznych, które nie wywołają szczelinowania lub innych komplikacji. Podczas projektowania zaczynów wykazujących odpowiednią stabilność sedymentacyjną należy się skoncentrować na odpowiednim doborze wielu parametrów, z których najbardziej istotnymi są parametry reologiczne (Stryczek et al., 2009; Kremieniewski, 2020).

Zaczyny cementowe łatwo ulegają sedymentacji, ponieważ zalicza się je do płynów wysoko zagęszczonych ze względu

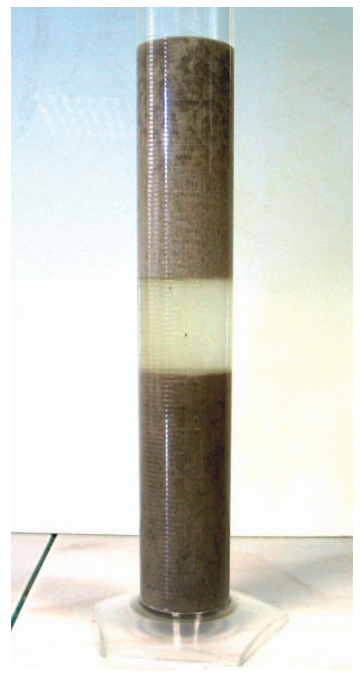

Rys. 1. Nadmierne frakcjonowanie zaczynu (mikrosfery obecne w górnych partiach) oraz sedymentacja (opadanie zaczynu w dolną część próbki)

Fig. 1. Excessive fractionation of the cement slurry (microspheres present in the upper parts) and sedimentation (cement slurry falling into the lower part of the sample)

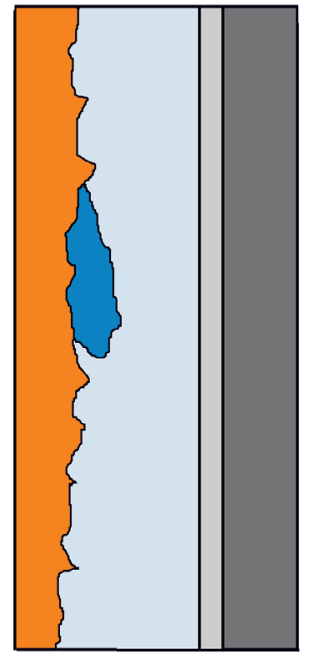

Rys. 2. Powstawanie ,kieszeni wodnych" na skutek nadmiernej ilości wody we frakcjonującym zaczynie

Fig. 2. The formation of "water spaces" due to excessive amounts of water in the fractionating cement slurry na znaczną, dochodzącą do 70\% zawartość fazy stałej. Ich parametry reologiczne są uzależnione od zawartości owej fazy stałej w stosunku do całej objętości oraz od oddziaływania cząsteczek w zawiesinie. Zaczyn cementowy to wodny roztwór jonów i dodatków organicznych. Gęstość zaczynu uzależniona jest od zawartości fazy stałej, a oddziaływania międzycząsteczkowe zależą od poziomu naładowania powierzchni składników obecnych w zaczynie, co wpływa na stabilność sedymentacyjną danej zawiesiny (Nelson, 1990; Wiśniowski et al., 2007).

W celu poprawy stabilności sedymentacyjnej zaczynu jednym z najczęściej stosowanych materiałów jest bentonit. Pozwala on uzyskać stabilną wartość granicy płynięcia oraz redukuje wytrącanie cząsteczek z zaczynu cementowego. Bentonit wykazuje właściwości absorpcyjne dużych ilości wody, dzięki czemu wpływa na homogenizację zaczynu cementowego. Jest to spowodowane możliwością nawet kilkukrotnej ekspansji pierwotnej objętości bentonitu, co powoduje wzrost lepkości, wytrzymałości strukturalnej i tym samym utrzymanie fazy stałej w całej objętości zatłoczonego zaczynu cementowego (Peng i Jacobsen, 2013; Kremieniewski, 2019c). 
Innym rodzajem środka wpływającego na poprawę stabilności sedymentacyjnej jest wodna dyspersja bezpostaciowej krzemionki (krzemianu sodu/krzemianu potasu), którą otrzymuje się w drodze syntezy. Jest to ciecz o gęstości $1,23 \mathrm{~g} / \mathrm{cm}^{3}$ zawierająca mikrokrzemionkę o rozwiniętej powierzchni właściwej, dzięki czemu działa ona stabilizująco w zaczynach cementowych. Zaczyn z dodatkiem krzemionki koloidalnej wykazuje mniejszą tendencję do sedymentowania na skutek wzrostu właściwości zagęszczających i tiksotropowych wodnej dyspersji $\mathrm{SiO}_{2}$. Dodatkowo krzemiany szybko wchodzą w reakcję z wolnym tlenkiem wapnia poprawiając stopień związania stwardniałego zaczynu cementowego. Struktura żelu wapniowo-krzemianowego powoduje wyraźny wzrost lepkości przy mieszaniu z dużą ilością wody bez ubocznego efektu wydzielania wody wolnej z zaczynu cementowego (Stryczek et al., 2005; Kremieniewski, 2019a). Jest to korzystne podczas projektowania zaczynów o wysokiej stabilności sedymentacyjnej. Szkło wodne $\left(\mathrm{Na}_{2} \mathrm{O} \cdot(3-5) \mathrm{SiO}_{2}\right)$ należy dodawać do wody zarobowej przed mieszaniem zaczynu cementowego. Przy stosowaniu wraz z chlorkiem wapnia, należy najpierw rozpuścić $\mathrm{CaCl}_{2}$ w wodzie zarobowej i dopiero później dozować pozostałe składniki w celu uzyskania optymalnych efektów (Stryczek et al., 2014; Kremieniewski, 2019d;).

Omówione w niniejszym artykule badania środków poprawiających homogeniczność zaczynu prowadzone są głównie na podstawie pomiaru frakcjonowania lekkich materiałów wypełniających w wodzie zarobowej z dodatkiem środków przeciwsedymentacyjnych. Jest to możliwe przy użyciu różnych technik badawczych, z których najbardziej wyrafinowane polegają na laserowym pomiarze rozkładu ilości cząstek w objętości cieczy w określonym punkcie pomiarowym. Z kolei w warunkach przemysłowych skutecznym pomiarem jest badanie gęstości zaczynu w sedymentacyjnej kolumnie pomiarowej (rys. 3). Na podstawie pomiaru gęstości zaczynu w poszczególnych punktach (góra, środek, dół) możliwe jest określenie frakcjonowania dyspersyjnego układu zaczynu cementowego. Jednak badanie to dotyczy gotowego zaczynu. Ze względu na to, że zaczyn zawiera w składzie różne dodatki i domieszki modyfikujące jego parametry to powyższe badanie stabilności sedymentacyjnej w kolumnie jest niedokładne podczas analizy danego środka przeciwsedymentacyjnego w celu wyeliminowania frakcjonowania materiałów lekkich. Dlatego też przed wykonaniem badań stabilności zaczynu cementowego korzystne jest przeprowadzenie testów wstępnych dla danego środka. Tego rodzaju badania służą do konkretnej weryfikacji działania wybranego środka pod kątem ograniczenia frakcjonowania lekkich materiałów wypełniających. Omówione w dalszej części publikacji badania frakcjonowania przeprowadzone dla środków poprawiających stabilność sedymentacyjną pozwalają na wytypowanie produktów o najlepszym działaniu, a następnie zastosowanie ich w projektowanej recepturze zaczynu cementowego.

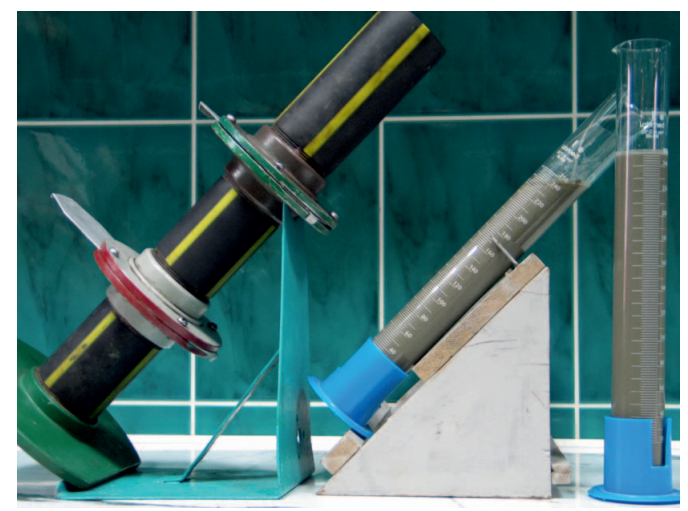

Rys. 3. Stanowisko do oznaczania stabilności sedymentacyjnej zaczynu cementowego i odstoju wody (po lewej kolumna sedymentacyjna, po prawej cylindry do pomiaru odstoju wody)

Fig. 3. Stand for determination of sediment stability of cement slurry and water retention (sedimentation column on the left, cylinders for measuring water separation on the right)

\section{Przebieg prac badawczych}

Badania środków poprawiających stabilność sedymentacyjną zaczynów cementowych zostały wykonane w Laboratorium Zaczynów Uszczelniających INiG - PIB. Lekkie dodatki w recepturze zaczynu ulegają frakcjonowaniu, ale jest to mało widoczne ze względu na brak przejrzystości zaczynu i ze względu na dużą jego lepkość. W związku z tym badania środków poprawiających stabilność sedymentacyjną zaczynów cementowych zostały wykonane według następującej metodyki. W wodzie $\left(250 \mathrm{~cm}^{3}\right)$ zawierającej 2,5\% lekkiego materiału wypełniającego (mikrosfera) zmieszano określoną (0,5\%; $1 \% ; 2,5 \% ; 5 \% ; 10 \%)$ ilość wytypowanego środka poprawiającego stabilność sedymentacyjną. Po wymieszaniu w elektrycznym mikserze cementowym z określoną prędkością obrotową (2000 obr/min) mieszaninę przelano do cylindra miarowego o pojemności $250 \mathrm{~cm}^{3}$. Następnie w odstępach czasowych równych 2,5 $\mathrm{min}, 5 \mathrm{~min}, 7,5 \mathrm{~min}, 10 \mathrm{~min}, 15 \mathrm{~min}$, 20 min oraz 30 min odczytywano ilość mikrosfer unoszących się w górnej części cylindra. Im większa objętość mikrosfer w górnej części tym lepsze działanie środka poprawiającego stabilność sedymentacyjną. Związane jest to z możliwością utrzymania lekkich cząstek w jak największej objętości cieczy zarobowej. W celu uzyskania kontrastu woda została zabarwiona $0,05 \%$ ilością barwnika. Na podstawie uzyskanych wyników możliwe było określenie siły działania danego środka poprawiającego stabilność sedymentacyjną w cieczy niskolepkiej, jaką jest woda.

Do badań wytypowano grupę następujących środków poprawiających stabilność sedymentacyjną zaczynów cementowych: 
- CBD75 (na osnowie wodnej dyspersji krzemianu sodu);

- XD (na bazie żywicy ksantanowej);

- GS (polimerowy środek o działaniu przeciwmigracyjnym);

- BTE (domieszka zawierająca montmorylonit);

- CMG (środek na bazie chlorku magnezu);

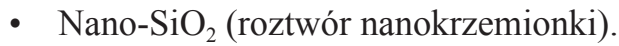

Następnie wykonane zostały badania, których celem było określenie frakcjonowania cieczy zawierających wytypowane do badań środki.

\section{Środek zapobiegający frakcjonowaniu CBD75}

Pierwszym poddanym badaniom środkiem przeciwsedymentacyjnym był CBD75. W tabeli 1 zestawiono wyniki badań frakcjonowania mikrosfery w zależności od stężenia CBD75 w wodzie zarobowej oraz od czasu trwania pomiaru. Na podstawie badań zaobserwowano znaczną objętość mikrosfer unoszących się w górnej części próbki zawierającej najmniejsze 0,5\%-owe stężenie CBD75. Bezpośrednio po przelaniu cieczy z miksera do cylindrów, widoczne było wydzielanie się

Tabela 1. Frakcjonowanie mikrosfer pod wpływem różnych stężeń środka CBD75 w zależności od czasu

Table 1. Fractionation of microspheres under the influence of different CBD75 concentrations depending on time

\begin{tabular}{|c|c|c|c|c|c|c|}
\hline \multirow{2}{*}{$\begin{array}{c}\text { Rysunek } \\
\text { numer }\end{array}$} & \multirow{6}{*}{$\begin{array}{c}\text { Czas } \\
\text { [minuty] }\end{array}$} & \multicolumn{5}{|c|}{ Objętość $\left[\mathbf{c m}^{3}\right.$ ] mikrosfer w górnej części } \\
\cline { 3 - 7 } & & $\mathbf{1}$ & $\mathbf{2}$ & $\mathbf{3}$ & $\mathbf{4}$ & $\mathbf{5}$ \\
\cline { 3 - 7 } & & $\mathbf{5}$ Stężenie środka & $\mathbf{5}$ \\
\cline { 3 - 7 } & & $\mathbf{0 , 5}$ & $\mathbf{1 , 0}$ & $\mathbf{2 , 5}$ & $\mathbf{5 , 0}$ & $\mathbf{1 0 , 0}$ \\
\hline \hline 5 & 0 & 26 & 24 & 22 & 18 & 8 \\
\hline 6 & 2,5 & 28 & 26 & 24 & 20 & 18 \\
\hline 7 & 5 & 30 & 30 & 26 & 24 & 20 \\
\hline & 30 & 30 & 30 & 26 & 24 & 20 \\
\hline
\end{tabular}

domieszki w zakresie od $8 \mathrm{~cm}^{3}$ do $26 \mathrm{~cm}^{3}$ (tab. 1, rys. 4, 5). Po czasie 2,5 minuty, w górnej części cylindra obserwowano wydzieloną mikrosferę w ilości od $28 \mathrm{~cm}^{3}$ przy stężeniu $0,5 \%$ środka CBD75 do $18 \mathrm{~cm}^{3}$ dla stężenia 10\% CBD75 w wodzie (tab. 1, rys. 4, 6). Natomiast po 5 minutach pomiaru domieszka mikrosfer ulegała w dalszym ciągu niewielkiemu frakcjonowaniu i po 2,5 minutach uzyskano w górnej części cylindra $30 \mathrm{~cm}^{3}$ mikrosfer, a w próbce o stężeniu 10\% CBD75 odnotowano $20 \mathrm{~cm}^{3}$ mikrosfer (tab. 1, rys. 4, 7). Takie ilości utrzymywały się do końca trwania pomiaru, czyli do odczytu po 30 minutach (zaznaczenie kolorem czerwonym w tab. 1). Graficzne porównanie frakcjonowania w zależności od czasu i stężenia użytych dodatków przedstawiono na rysunkach 5, 6 i 7. Na podstawie prowadzonych badań stwierdzono, że wraz ze wzrostem czasu trwania pomiaru mikrosfery w górnej części cylindra zmniejszały swą objętość.

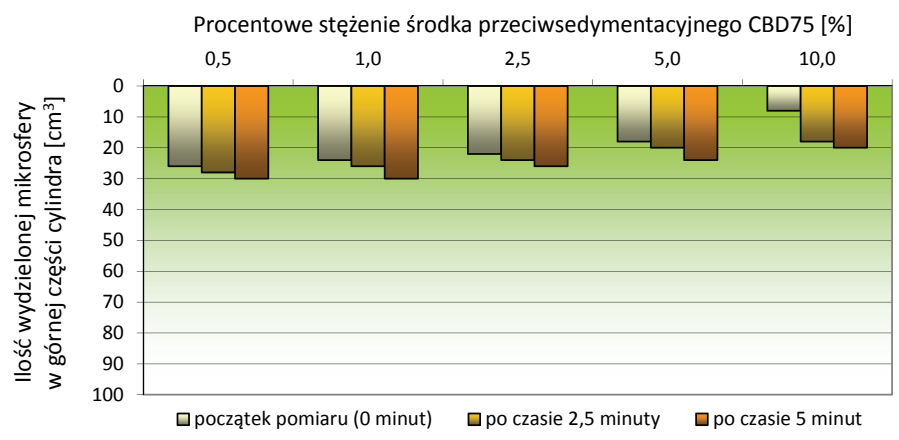

Rys. 4. Wydzielanie się mikrosfer $\mathrm{w}$ górnej części cylindra w próbkach zawierających CBD75

Fig. 4. Floating microspheres at the top of the cylinder in samples containing CBD75

\section{Środek zapobiegający frakcjonowaniu XD (na bazie żywicy ksantanowej)}

Drugim wytypowanym do badań materiałem zapobiegającym frakcjonowaniu był środek XD sporządzony na bazie

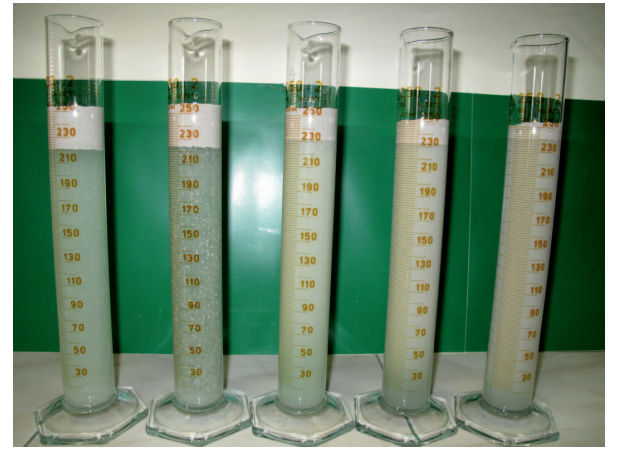

Rys. 5. Frakcjonowanie mikrosfer $\mathrm{z}$ dodatkiem przeciwsedymentacyjnym CBD75 na początku pomiaru

Fig. 5. Fractionation of microspheres with the CBD75 anti-sedimentation additive at the beginning of the measurements

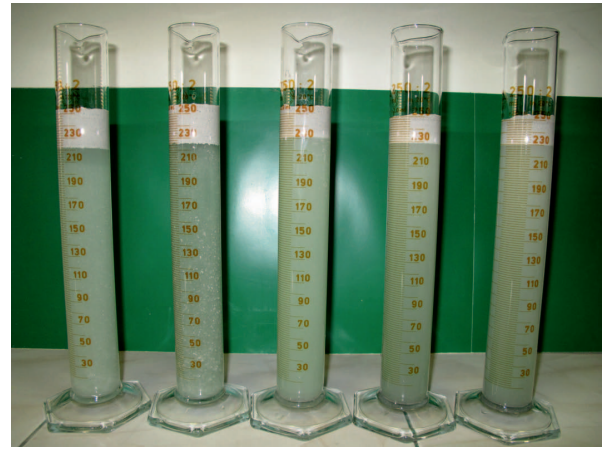

Rys. 6. Frakcjonowanie mikrosfer $\mathrm{z}$ dodatkiem przeciwsedymentacyjnym CBD75 po czasie 2,5 minut

Fig. 6. Fractionation of microspheres with the CBD75 anti-sedimentation additive after 2.5 minutes

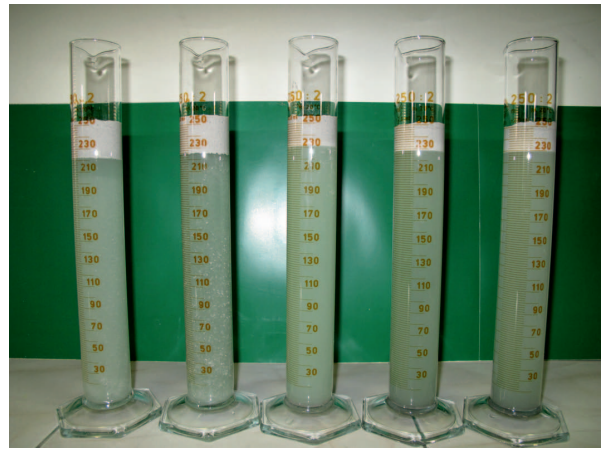

Rys. 7. Frakcjonowanie mikrosfer z dodatkiem przeciwsedymentacyjnym CBD75 po czasie 5 minut

Fig. 7. Fractionation of microspheres with the CBD75 anti-sedimentation additive after 5 minutes 
żywicy ksantanowej. Na podstawie analizy uzyskanych wyników badań (tab. 2) również zaobserwowano frakcjonowanie od razu po przelaniu cieczy do cylindra, ale głównie w próbkach o stężeniu XD nieprzekraczającym 2,5\% (rys. 9). Mikrosfera wydzielała się w górniej części cylindra w zakresie od $32 \mathrm{~cm}^{3}$ przy stężeniu $0,5 \%$ XD do $39 \mathrm{~cm}^{3}$ przy stężeniu 2,5\% XD (tab. 2, rys. 8, 9). Próbki o stężeniu XD w zakresie stężeń od 5\% do $10 \%$ nie ulegały frakcjonowaniu w początkowym czasie pomiaru i wartość mikrosfer w górnej części cylindra wynosiła $250 \mathrm{~cm}^{3}$. Po czasie 2,5 minuty frakcjonowanie wynosiło od $34 \mathrm{~cm}^{3}$ dla stężenia $0,5 \%$ do $30 \mathrm{~cm}^{3}$ dla stężenia $5 \%$ (tab. 2 , rys. 8,10 ). Natomiast próbka zawierająca $10 \% \mathrm{XD}$ w dalszym ciągu nie frakcjonowała. Taki stan utrzymał się do końca trwania pomiaru, czyli do odczytu po $30 \mathrm{mi}-$ nutach i po tym czasie próbka zawierająca 10\% środka przeciwsedymentacyjnego XD również nie ulegała frakcjonowaniu (rys. 11). Po zastosowaniu środka XD zaobserwowano, iż wraz ze wzrostem koncentracji XD w zakresie od 0,5\% do 2,5\% ilość wydzielającej się mikrosfery wzrastała. Świadczy to o dobrych właściwościach przeciwsedymentacyjnych środka XD.

Tabela 2. Frakcjonowanie mikrosfer pod wpływem różnych stężeń środka XD w zależności od czasu

Table 2. Fractionation of microspheres under the influence of different XD concentrations depending on time

\begin{tabular}{|c|c|c|c|c|c|c|}
\hline \multirow{2}{*}{$\begin{array}{c}\text { Rysunek } \\
\text { numer }\end{array}$} & \multirow{5}{*}{$\begin{array}{c}\text { Czas } \\
\text { [minuty] }\end{array}$} & \multicolumn{5}{|c|}{ Objętość $\left[\mathbf{c m}^{3}\right.$ ] mikrosfer w górnej części } \\
\cline { 3 - 7 } & & $\mathbf{1}$ & $\mathbf{2}$ & $\mathbf{3}$ & $\mathbf{4}$ & $\mathbf{5}$ \\
\cline { 3 - 7 } & & \multicolumn{5}{|c|}{$\begin{array}{c}\text { Stężenie środka } \\
\text { przeciwsedymentacyjnego [\%] }\end{array}$} \\
\cline { 3 - 7 } & & $\mathbf{0 , 5}$ & $\mathbf{1 , 0}$ & $\mathbf{2 , 5}$ & $\mathbf{5 , 0}$ & $\mathbf{1 0 , 0}$ \\
\hline \hline 9 & 0 & 32 & 34 & 39 & 250 & 250 \\
\hline 10 & 2,5 & 34 & 36 & 38 & 30 & 250 \\
\hline 11 & 30 & 34 & 36 & 38 & 30 & 0 \\
\hline
\end{tabular}

Koncentracja 5\% środka XD powodowała mocne obniżenie frakcjonowania, a 10\%-owa zawartość XD zatrzymała frakcjonowanie mikrosfer.

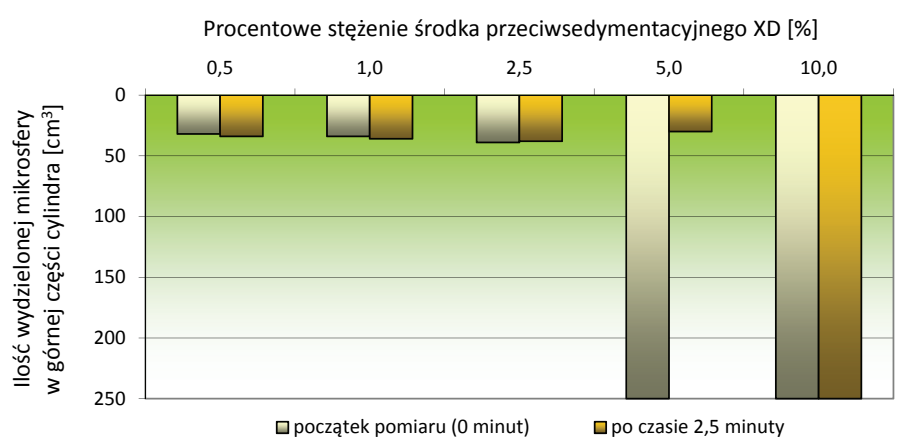

Rys. 8. Wydzielanie się mikrosfer w górnej części cylindra w próbkach zawierających XD

Fig. 8. Floating microspheres at the top of the cylinder in samples containing XD

\section{GS (polimerowy środek o działaniu przeciwmigracyjnym)}

Trzecim spośród badanych środków przeciwsedymentacyjnych był GS. Analizując uzyskane wyniki badań (tab. 3) zaobserwowano frakcjonowanie po przelaniu cieczy do cylindra. Mikrosfera wydzielała się w zakresie od $10 \mathrm{~cm}^{3}$ przy stężeniu $0,5 \%$ do $2 \mathrm{~cm}^{3}$ przy $10 \%$-owym stężeniu środka GS (tab. 3, rys. 12, 13). Po 2,5 minutach objętość mikrosfer niewiele wzrosła uzyskując wartości w zakresie od $14 \mathrm{~cm}^{3}$ dla stężenia $0,5 \%$ GS do $6 \mathrm{~cm}^{3}$ dla stężenia $10 \%$ (tab. 3, rys. 12, 14). Po czasie pomiaru równym 5 minut frakcjonowanie mikrosfer wynosiło od $14 \mathrm{~cm}^{3}$ dla stężenia $0,5 \% \mathrm{GS}$ do $10 \mathrm{~cm}^{3}$ dla stężenia $10 \%$ (tab. 3 , rys. 12,15 ) i takie wartości utrzymały się do końcowego etapu testu (30 minut). Jednak porównując obrazy frakcjonowania (rys. 13 do 15) zaobserwowano, że cząsteczki mikrosfer utrzymują się w objętości cieczy, więc środek GS wykazuje działanie przeciwsedymentacyjne.

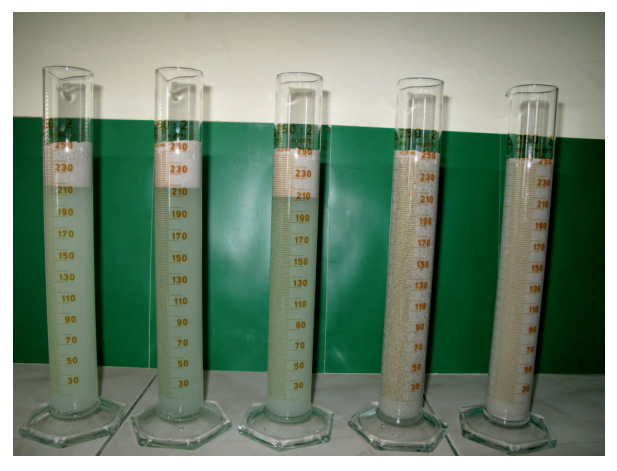

Rys. 9. Frakcjonowanie mikrosfer $\mathrm{z}$ dodatkiem przeciwsedymentacyjnym XD na początku pomiaru

Fig. 9. Fractionation of microspheres with the XD anti-sedimentation additive at the beginning of the measurements

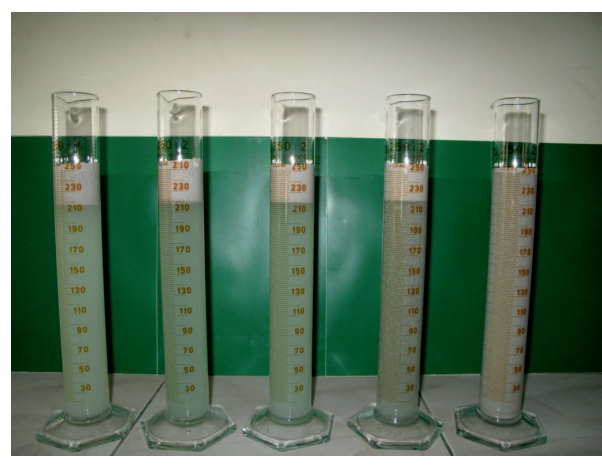

Rys. 10. Frakcjonowanie mikrosfer $\mathrm{z}$ dodatkiem przeciwsedymentacyjnym XD po czasie 2,5 minut

Fig. 10. Fractionation of microspheres with the XD anti-sedimentation additive after 2.5 minutes

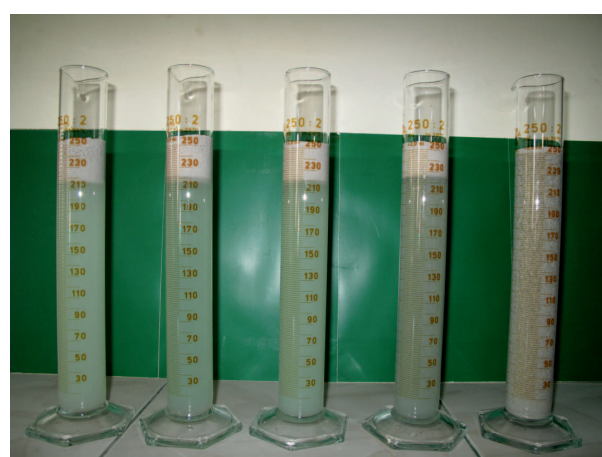

Rys. 11. Frakcjonowanie mikrosfer $z$ dodatkiem przeciwsedymentacyjnym XD po czasie 30 minut

Fig. 11. Fractionation of microspheres with the XD anti-sedimentation additive after 30 minutes 
Tabela 3. Frakcjonowanie mikrosfer pod wpływem różnych stężeń środka GS w zależności od czasu

Table 3. Fractionation of microspheres under the influence of different GS concentrations depending on time

\begin{tabular}{|c|c|c|c|c|c|c|}
\hline \multirow{2}{*}{$\begin{array}{c}\text { Rysunek } \\
\text { numer }\end{array}$} & \multirow{5}{*}{$\begin{array}{c}\text { Czas } \\
\text { [minuty] }\end{array}$} & \multicolumn{5}{|c|}{ Objętość $\left[\mathbf{c m}^{3}\right.$ ] mikrosfer w górnej części } \\
\cline { 3 - 7 } & & $\mathbf{1}$ & $\mathbf{1}$ & $\mathbf{1}$ & $\mathbf{1}$ & $\mathbf{1}$ \\
\cline { 3 - 7 } & & $\mathbf{5}$ Stężenie środka \\
\cline { 3 - 7 } & & $\mathbf{0 , 5}$ & $\mathbf{1 , 0}$ & $\mathbf{2 , 5}$ & $\mathbf{5 , 0}$ & $\mathbf{1 0 , 0}$ \\
\hline \hline 13 & 0 & 10 & 8 & 6 & 4 & 2 \\
\hline 14 & 2,5 & 14 & 12 & 12 & 8 & 6 \\
\hline 15 & 5 & 14 & 14 & 14 & 14 & 10 \\
\hline & 30 & 14 & 14 & 14 & 14 & 16 \\
\hline
\end{tabular}

Procentowe stężenie środka przeciwsedymentacyjnego GS [\%]

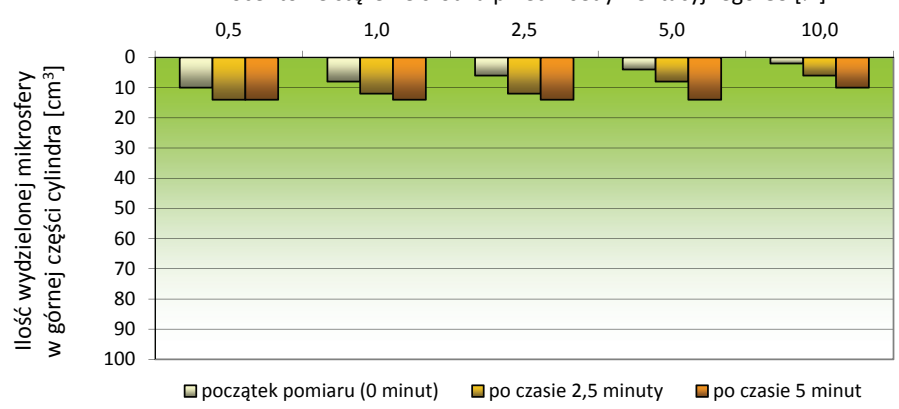

Rys. 12. Wydzielanie się mikrosfer w górnej części cylindra w próbkach zawierających GS

Fig. 12. Floating microspheres at the top of the cylinder in samples containing GS

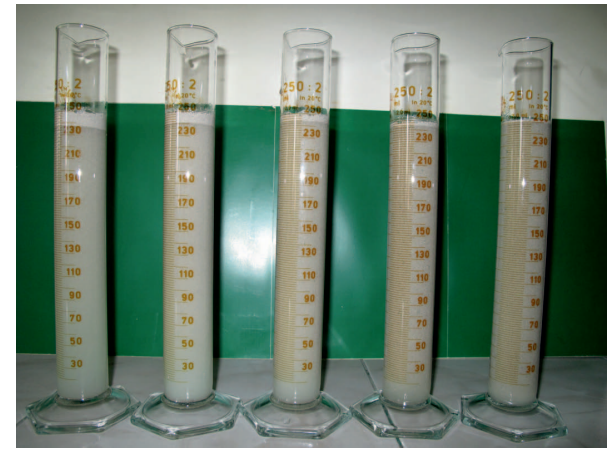

Rys. 13. Frakcjonowanie mikrosfer $\mathrm{z}$ dodatkiem przeciwsedymentacyjnym GS na początku pomiaru

Fig. 13. Fractionation of microspheres with the GS anti-sedimentation additive at the beginning of the measurements

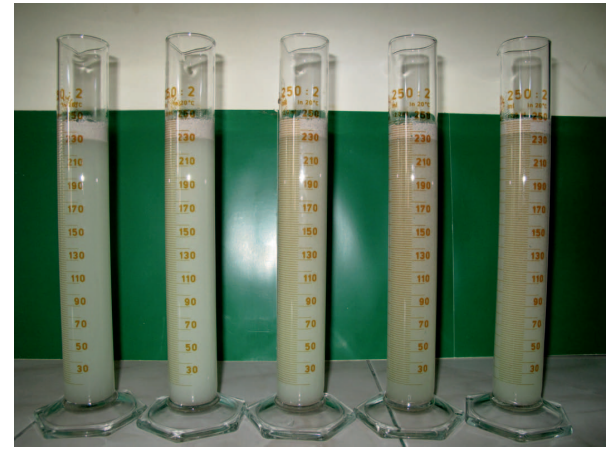

Rys. 14. Frakcjonowanie mikrosfer $\mathrm{z}$ dodatkiem przeciwsedymentacyjnym GS po czasie 2,5 minut

Fig. 14. Fractionation of microspheres with the GS anti-sedimentation additive after 2.5 minutes

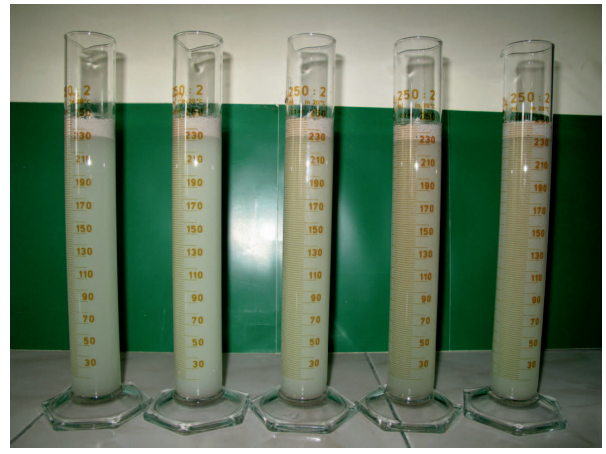

Rys. 15. Frakcjonowanie mikrosfer $\mathrm{z}$ dodatkiem przeciwsedymentacyjnym GS po czasie 5 minut

Fig. 15. Fractionation of microspheres with the GS anti-sedimentation additive after 5 minutes

\section{BTE (domieszka zawierająca montmorylonit)}

Czwartym środkiem stosowanym w celu ograniczenia frakcjonowania był środek BTE - domieszka zawierająca montmorylonit. Analizując zestawione w tabeli 4 wyniki badań

Tabela 4. Frakcjonowanie mikrosfer pod wpływem różnych stężeń środka BTE w zależności od czasu

Table 4. Fractionation of microspheres under the influence of different BTE concentrations depending on time

\begin{tabular}{|c|c|c|c|c|c|c|}
\hline \multirow{5}{*}{$\begin{array}{l}\text { Rysunek } \\
\text { numer }\end{array}$} & \multirow{5}{*}{$\begin{array}{c}\text { Czas } \\
{[\text { minuty] }}\end{array}$} & \multirow{2}{*}{\multicolumn{5}{|c|}{$\begin{array}{c}\text { Objętość }\left[\mathrm{cm}^{3}\right] \text { mikrosfer w górnej części } \\
\text { Próbka nr (na rys. licząc od lewej str.) }\end{array}$}} \\
\hline & & & & & & \\
\hline & & 1 & 2 & 3 & 4 & 5 \\
\hline & & \multicolumn{5}{|c|}{$\begin{array}{c}\text { Stężenie środka } \\
\text { przeciwsedymentacyjnego [\%] }\end{array}$} \\
\hline & & 0,5 & 1,0 & 2,5 & 5,0 & 10,0 \\
\hline 17 & 0 & 240 & 250 & 250 & 250 & 250 \\
\hline 18 & 2,5 & 230 & 250 & 250 & 250 & 250 \\
\hline 19 & 30 & 150 & 180 & 240 & 250 & 250 \\
\hline
\end{tabular}

stwierdzono bardzo mocne przeciwdziałanie frakcjonowaniu obecnych w wodzie mikrosfer. Po przelaniu próbek do cylindrów miarowych w początkowym okresie czasu mikrosfera widoczna była niemal w całej $\left(240 \mathrm{~cm}^{3}\right)$ objętości cylindra (tab. 4, rys. 16, 17). Po 2,5 minutach frakcjonowanie wzrosło

Procentowe stężenie środka przeciwsedymentacyjnego BTE [\%]

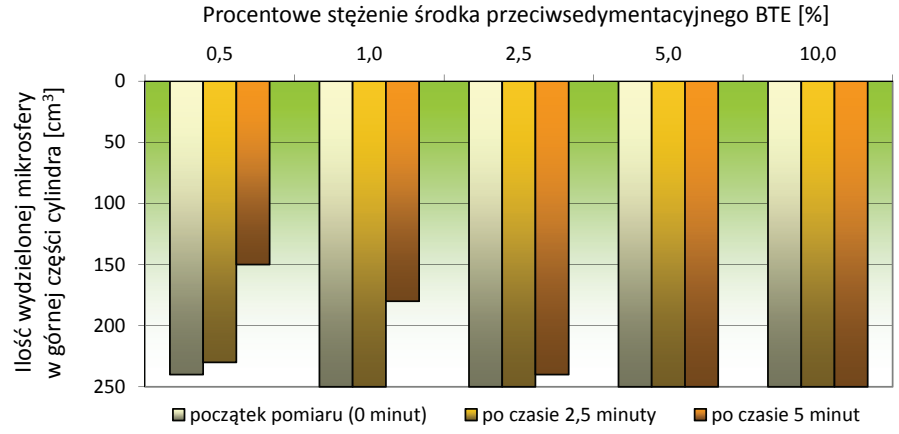

Rys. 16. Wydzielanie się mikrosfer w górnej części cylindra w próbkach zawierających BTE

Fig. 16. Floating microspheres at the top of the cylinder in samples containing BTE 


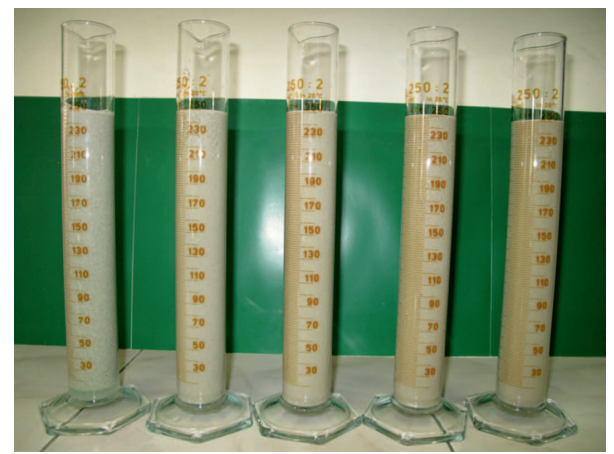

Rys. 17. Frakcjonowanie mikrosfer $\mathrm{z}$ dodatkiem przeciwsedymentacyjnym BTE na początku pomiaru

Fig. 17. Fractionation of microspheres with the BTE anti-sedimentation additive at the beginning of the measurements

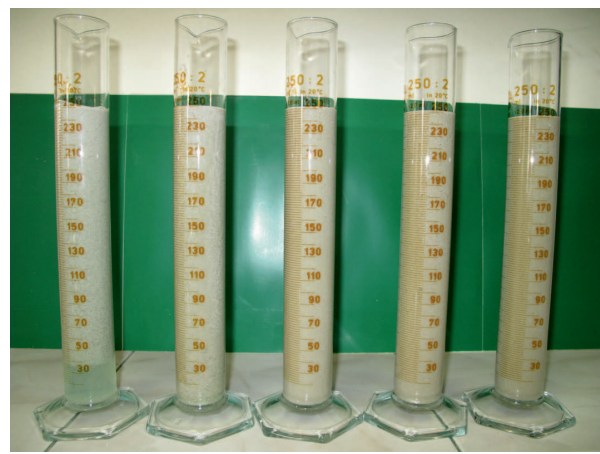

Rys. 18. Frakcjonowanie mikrosfer $z$ dodatkiem przeciwsedymentacyjnym BTE po czasie 2,5 minut

Fig. 18. Fractionation of microspheres with the BTE anti-sedimentation additive after 2.5 minutes

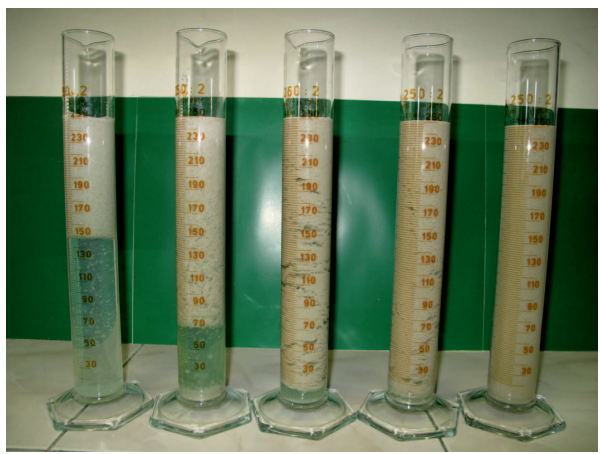

Rys. 19. Frakcjonowanie mikrosfer $z$ dodatkiem przeciwsedymentacyjnym BTE po czasie 30 minut

Fig. 19. Fractionation of microspheres with the BTE anti-sedimentation additive after 30 minutes o $10 \mathrm{~cm}^{3}$ uzyskując wartości w zakresie od $230 \mathrm{~cm}^{3}$ przy koncentracji BTE $0,5 \%$. W próbkach o większym stężeniu BTE nie stwierdzono frakcjonowania i objętość mikrosfery wynosiła $250 \mathrm{~cm}^{3}$ (tab. 4, rys. 16, 18). W końcowym etapie testu po upływie 30 minut odnotowano frakcjonowanie w próbce o koncentracji 0,5\% BTE, gdzie objętość mikrosfer wynosiła $150 \mathrm{~cm}^{3}$. Koncentracja BTE $1 \%$ powodowała zmniejszenie frakcjonowania objawiające się objętością mikrosfer wynoszącą $180 \mathrm{~cm}^{3}$, natomiast przy koncentracji 2,5\% BTE odnotowano $240 \mathrm{~cm}^{3}$ mikrosfer w cylindrze miarowym o pojemności $250 \mathrm{~cm}^{3}$ (tab. 4, rys. 16, 19). Optymalnym stężeniem środka BTE jest wartość 1\%

\section{CMG (środek na bazie chlorku magnezu)}

Kolejnym środkiem, który został poddany testowi pod kątem zastosowania w celu ograniczenia frakcjonowania był CMG, czyli środek na bazie chlorku magnezu. Analizując uzyskane wyniki badań (tab. 5) stwierdzono mocne frakcjonowanie po przelaniu cieczy do cylindra. Mikrosfera wydzielała

Tabela 5. Frakcjonowanie mikrosfer pod wpływem różnych stężeń środka CMG w zależności od czasu

Table 5. Fractionation of microspheres under the influence of different $\mathrm{CMG}$ concentrations depending on time

\begin{tabular}{|c|c|c|c|c|c|c|}
\hline \multirow{2}{*}{$\begin{array}{c}\text { Rysunek } \\
\text { nr }\end{array}$} & \multirow{2}{*}{$\begin{array}{c}\text { Czas } \\
\text { [minuty] }\end{array}$} & \multicolumn{5}{|c|}{ Objętość $\left[\mathbf{c m}^{3}\right.$ ] mikrosfer w górnej części } \\
\cline { 3 - 7 } & & $\mathbf{5}$ & $\mathbf{5}$ & $\mathbf{3}$ & $\mathbf{4}$ & $\mathbf{5}$ \\
\cline { 3 - 7 } & & $\begin{array}{c}\text { Stężenie środka nr (na rys. licząc od lewej str.) } \\
\text { przeciwsedymentacyjnego [\%] }\end{array}$ \\
\cline { 3 - 7 } & & $\mathbf{0 , 5}$ & $\mathbf{1 , 0}$ & $\mathbf{2 , 5}$ & $\mathbf{5 , 0}$ & $\mathbf{1 0 , 0}$ \\
\hline \hline 21 & 0 & 12 & 10 & 6 & 6 & 6 \\
\hline 22 & 2,5 & 14 & 14 & 14 & 14 & 14 \\
\hline & 30 & 14 & 14 & 14 & 14 & 14 \\
\hline
\end{tabular}

się w zakresie od $12 \mathrm{~cm}^{3}$ przy stężeniu $0,5 \%$ do $6 \mathrm{~cm}^{3}$ przy 10\%-owym stężeniu CMG (tab. 5, rys. 20, 21). Natomiast po 2,5 minutach frakcjonowanie było na niemal niezmiennym poziomie i wynosiło $14 \mathrm{~cm}^{3}$ dla wszystkich stężeń CMG i takie wartości utrzymały się do końcowego etapu testu, tj. 30 minut (tab. 5, rys. 20, 22). Środek ten wykazywał bardzo słabe działanie przeciwsedymentacyjne podczas prowadzonych testów.

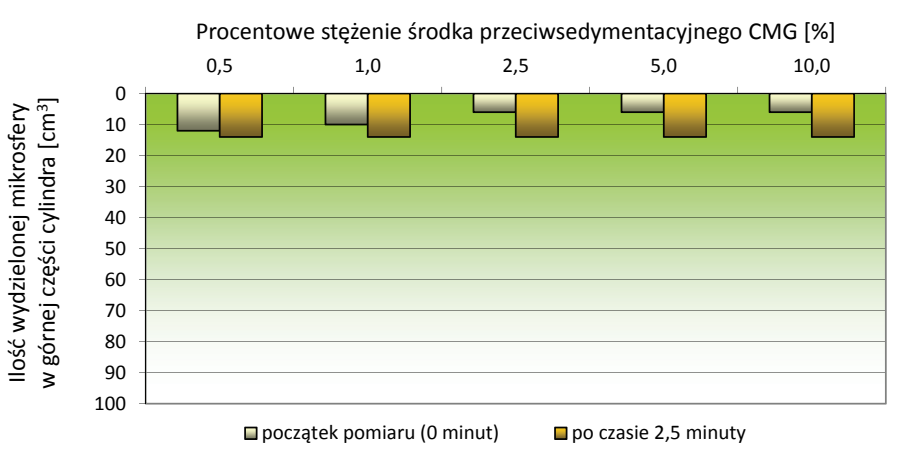

Rys. 20. Wydzielanie się mikrosfer w górnej części cylindra w próbkach zawierających CMG

Fig. 20. Floating microspheres at the top of the cylinder in samples containing $\mathrm{CMG}$

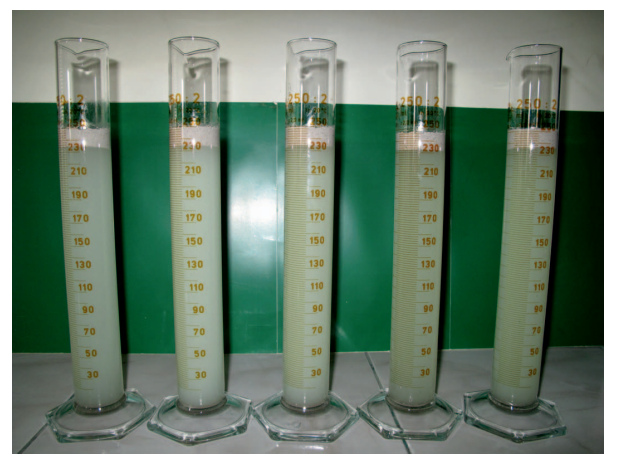

Rys. 21. Frakcjonowanie mikrosfer z dodatkiem przeciwsedymentacyjnym CMG na początku pomiaru

Fig. 21. Fractionation of microspheres with the CMG anti-sedimentation additive at the beginning of the measurements 


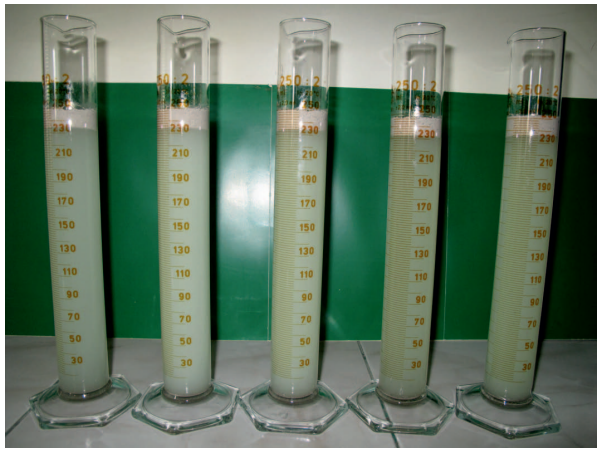

Rys. 22. Frakcjonowanie mikrosfer $\mathrm{z}$ dodatkiem przeciwsedymentacyjnym $\mathrm{CMG}$ po czasie 2,5 minut

Fig. 22. Fractionation of microspheres with the CMG anti-sedimentation additive after 2.5 minutes

\section{Nano-SiO ${ }_{2}$ (roztwór nanokrzemionki)}

Ostatnim środkiem poddanym badaniom był nano- $\mathrm{SiO}_{2}-$ roztwór nanokrzemionki. Na podstawie zestawionych w tabeli 6 wyników (podobnie jak w przypadku poprzedniego środka CMG) stwierdzono mocne frakcjonowanie mikrosfery, która wydzielała się w zakresie od $12 \mathrm{~cm}^{3}$ przy stężeniu $0,5 \%$ do $6 \mathrm{~cm}^{3}$ przy $10 \%$-owym stężeniu nano- $\mathrm{SiO}_{2}$ (tab. 6 , rys. 23, 24).

Tabela 6. Frakcjonowanie mikrosfer pod wpływem różnych stężeń Nano- $\mathrm{SiO}_{2}$ w zależności od czasu

Table 6. Fractionation of microspheres under the influence of different $\mathrm{Nano}-\mathrm{SiO}_{2}$ concentrations depending on time

\begin{tabular}{|c|c|c|c|c|c|c|}
\hline \multirow{2}{*}{$\begin{array}{c}\text { Rysunek } \\
\text { numer }\end{array}$} & $\begin{array}{c}\text { Objętość } \text { [cm }{ }^{3} \text { ] mikrosfer w górnej części } \\
\text { [minuty] }\end{array}$ & \multicolumn{5}{|c|}{ Próbka nr" (na rys. licząc od lewej str.) } \\
\cline { 3 - 7 } & & $\mathbf{1}$ & $\mathbf{2}$ & $\mathbf{3}$ & $\mathbf{4}$ & $\mathbf{5}$ \\
\cline { 3 - 7 } & & $\mathbf{5 , 5}$ & $\mathbf{1 , 0}$ & $\mathbf{2 , 5}$ & $\mathbf{5 , 0}$ & $\mathbf{1 0 , 0}$ \\
\cline { 3 - 7 } & & 12 & 10 & 10 & 8 & 6 \\
\hline \hline 24 & 0 & 14 & 16 & 16 & 16 & 16 \\
\hline 25 & 2,5 & 16 & 16 & 16 & 16 & 16 \\
\hline & 30 & &
\end{tabular}

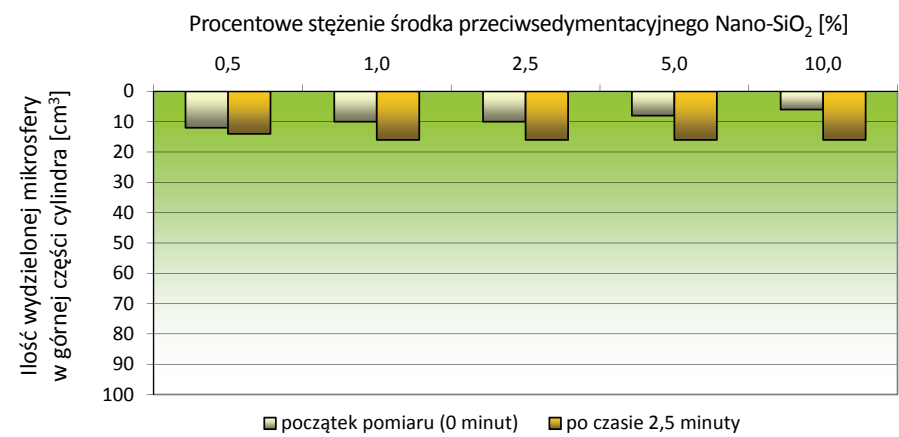

Rys. 23. Wydzielanie się mikrosfer w górnej części cylindra w próbkach zawierających $\mathrm{Nano}-\mathrm{SiO}_{2}$

Fig. 23. Floating microspheres at the top of the cylinder in samples containing Nano- $\mathrm{SiO}_{2}$
Po 2,5 minutach frakcjonowanie wynosiło $14 \mathrm{~cm}^{3}$ przy stężeniu $0,5 \%$ nano- $\mathrm{SiO}_{2} \mathrm{i}$ wzrosło do $16 \mathrm{~cm}^{3}$ dla pozostałych próbek, a stan taki pozostał do końca testu (tab. 5, rys. 23, 25). Nano$\mathrm{SiO}_{2}$ wykazuje bardzo słabe działanie przeciwsedymentacyjne.

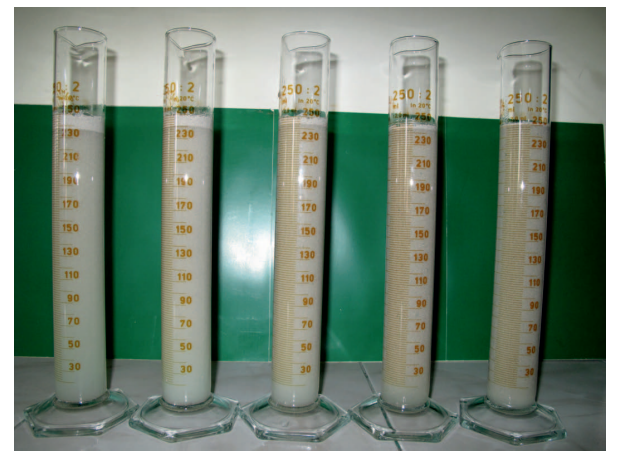

Rys. 24. Frakcjonowanie mikrosfer $\mathrm{z}$ dodatkiem przeciwsedymentacyjnym $\mathrm{Nano}-\mathrm{SiO}_{2}$ na początku pomiaru

Fig. 24. Fractionation of microspheres with the Nano- $\mathrm{SiO}_{2}$ antisedimentation additive at the beginning of the measurements

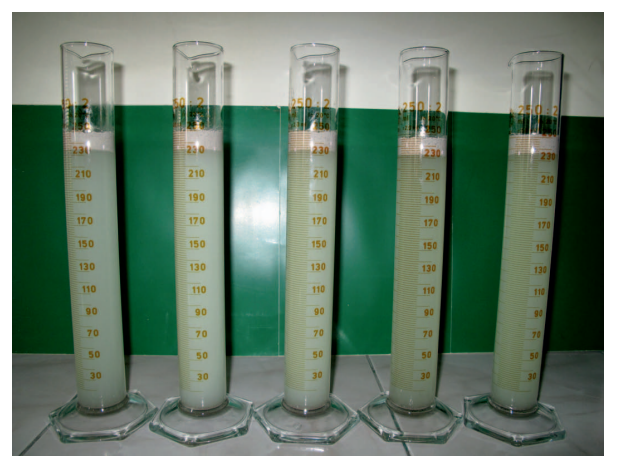

Rys. 25. Frakcjonowanie mikrosfer $\mathrm{z}$ dodatkiem przeciwsedymentacyjnym $\mathrm{Nano}_{-} \mathrm{SiO}_{2}$ po czasie 2,5 minut

Fig. 25. Fractionation of microspheres with the Nano- $\mathrm{SiO}_{2}$ antisedimentation additive after 2.5 minutes

\section{Wnioski}

1. Analizując uzyskane wyniki prowadzonych badań stwierdzono najsłabsze działanie zapobiegające frakcjonowaniu dla środków CMG i Nano- $\mathrm{SiO}_{2}$. Jednak badania frakcjonowania prowadzono dla cieczy wzorcowej, którą była woda. W przypadku zaczynu cementowego, środki te mogą wykazywać lepsze działanie przeciwdziałające frakcjonowaniu.

2. Środkami, które w najlepszym stopniu przeciwdziałały frakcjonowaniu były: CBD75, XD, GS i BTE. Podczas wprowadzenia CBD75 do wody widoczna była duża objętość wydzielona w górnej części mikrosfer. Potwierdza to korzystne działanie przeciwsedymentacyjne dla zaczynu. Jeszcze mocniejsze działanie wykazywał środek XD, gdyż po zastosowaniu jego 10\%-owej koncentracji, mikrosfery utrzymywały się w całej objętości cieczy nie ulegając frakcjonowaniu. 
3. Polimer o działaniu przeciwmigracyjnym w zaczynach cementowych również posiadał właściwości zapobiegające frakcjonowaniu. Jednak po wprowadzeniu do cieczy zarobowej środka GS, zaobserwowano również część mikrosfer w dolnych partiach cylindra, co przedstawiają rysunki od 13 do 15.

4. Najmocniejsze działanie ograniczające frakcjonowanie lekkich domieszek wykazywał środek BTE. Już od najmniejszej z badanych koncentracji 0,5\% zaobserwowano bardzo mocne działanie przeciwsedymentacyjne. Mikrosfery utrzymywały się w całej objętości wody. Po zastosowaniu BTE frakcjonowanie następowało dopiero po dhuższym czasie i tylko w próbkach o najmniejszych stężeniach $(0,5 \%$ i 1,0\%). Od stężenia 2,5\% BTE w wodzie frakcjonowanie mikrosfer nie następowało. Należy zaznaczyć, że w recepturze zaczynu cementowego można obniżyć koncentrację środka BTE ze względu, iż zaczyn posiada wyższą lepkość niż użyta do testów woda.

Przedstawiona w niniejszej publikacji metodyka badań oraz uzyskane wyniki mogą być bardzo pomocne przy doborze jakościowym środków poprawiających stabilność sedymentacyjną projektowanego zaczynu cementowego. Jest to bardzo ważne podczas projektowania zaczynów lekkich, które zawierają znaczną ilość wypełniaczy obniżających gęstość zaczynu.

Artykuł powstał na podstawie prac badawczych pt.: Analiza możliwości poprawy stabilności sedymentacyjnej zaczynów cementowych - praca INiG - PIB na zlecenie MNiSW; nr zlecenia: 0036/ KW/2016, nr archiwalny: DK-4100-0036/2016 oraz Analiza możliwości doszczelnienia mikrostruktury płaszcza cementowego za pomoca nowych domieszek drobnoziarnistych - praca INiG - PIB na zlecenie MNiSW; nr zlecenia: 0044/KW/2019, nr archiwalny: DK-4100-0034/2019.

\section{Literatura}

Jordan A., Pernites R., Albrighton L., 2018. Low-density, lightweight cement tested as alternative to reduce lost circulation, achieve desired top of cement in long horizontal wells. Drillingcontactor, September/October: 62-64.

Kremieniewski M., 2017a. Poprawa stabilności sedymentacyjnej zaczynu cementowego. Nafta-Gaz, 4: 242-249. DOI: 10.18668/ NG.2017.04.04.

Kremieniewski M., 2017b. Wpływ perlitu pylistego na własności technologiczne zaczynu cementowego. Nafta-Gaz, 12: 943-952. DOI: 10.18668/NG.2017.12.05.

Kremieniewski M., 2018. Poprawa wczesnej wytrzymałości mechanicznej płaszcza cementowego powstałego z zaczynu lekkiego. Nafta-Gaz, 8: 599-605. DOI: 10.18668/NG.2018.08.06.
Kremieniewski M., 2019a. Korelacja wyników badań filtracji i wczesnej wytrzymałości mechanicznej zaczynów cementowych z dodatkiem mączki krzemionkowej. Nafta-Gaz, 7: 394-403. DOI: 10.18668/NG.2019.07.03.

Kremieniewski M., 2019b. Receptury zaczynów do uszczelniania kolumn rur posadowionych w otworach wierconych w skałach chłonnych. Nafta-Gaz, 8: 451-457. DOI: 10.18668/NG.2019.08.01.

Kremieniewski M., 2019c. Rola plastyfikatora w projektowaniu zaczynu lekkiego o podwyższonej stabilności sedymentacyjnej. Nafta-Gaz, 9: 571-578. DOI: 10.18668/NG.2019.09.06.

Kremieniewski M., 2019d. Korelacja wyników badań wytrzymałości na ściskanie i przyczepności do rur stalowych płaszcza cementowego z zaczynu o obniżonej gęstości. Nafta-Gaz, 10: 613-624. DOI: $10.18668 /$ NG.2019.10.03.

Kremieniewski M., 2020. Zmiana parametrów reologicznych zaczynu lateksowego pod wpływem dodatku mikrosfery. Nafta-Gaz, 1: 37-45. DOI: 10.18668/NG.2020.01.05.

Kremieniewski M., Stryczek S., 2019. Zastosowanie cementu wysokoglinowego do sporządzania zaczynów uszczelniających w technologiach wiertniczych. Cement Wapno Beton, 3: 215-226.

Kremieniewski M., Stryczek S., Wiśniowski R., Gonet A., 2016. Zmniejszanie porowatości stwardniałych zaczynów wiertniczych poprzez wprowadzenie dodatków drobnoziarnistych. Cement Wapno Beton, 5: 325-335.

Nelson E.B. (ed.), 1990. Well Cementing, Schlumberger Educational Service, Houston, Texas, USA.

Peng Y., Jacobsen S., 2013. Influence of water/cement ratio, admixtures and filler on sedimentation and bleeding of cement paste. Cement and Concrete Research, 54: 133-142. DOI: 10.1016/j. cemconres.2013.09.003.

Stryczek S., Gonet A., Wiśniowski R., 2005. Wpływ wybranego dodatku mineralnego na własności technologiczne zaczynów cementowych. Wiertnictwo, Nafta, Gaz, 22/1: 333-341.

Stryczek S., Wiśniowski R., Gonet A., Ferens W., 2009. Parametry reologiczne świeżych zaczynów uszczelniających w zależności od czasu ich sporządzania. Wiertnictwo, Nafta, Gaz, 26/1-2: 369-382.

Stryczek S., Wiśniowski R., Gonet A., Złotkowski A., 2014 The influence of time of rheological parameters of fresh cement slurries. AGH Drilling, Oil, Gas, 31: 123-133. DOI: 10.7494/ drill.2014.31.1.123.

Wiśniowski R., Stryczek S., Skrzypaszek K., 2007. Kierunki rozwoju badań nad reologią płynów wiertniczych. Wiertnictwo, Nafta, Gaz, 24: 595-607.

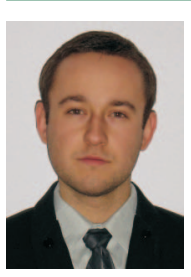

Dr inż. Marcin KREMIENIEWSKI

Adiunkt w Zakładzie Technologii Wiercenia Instytut Nafty i Gazu - Państwowy Instytut Badawczy ul. Lubicz 25 A

31-503 Kraków

E-mail: marcin.kremieniewski@inig.pl 